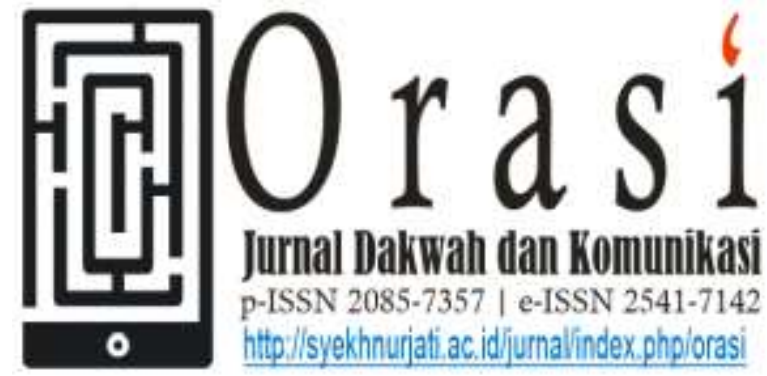

Volume 11 No. 2 Desember 2020

\title{
REPRESENTASI KORBAN COVID-19 DALAM FOTO JURNALISTIK DI INSTAGRAM @JOSHIRWANDI (Analisis Semiotik Roland Barthes)
}

\author{
REPRESENTATION OF A COVID-19 VICTIM \\ THROUGH PHOTOJOURNALISM \\ ON AN INSTAGRAM ACCOUNT@JOSHIRWANDI \\ (Roland Barthes' Semiotic Analysis)
}

\author{
Rani Ika Wijayanti'1,a), Mochamad Syaefudin ${ }^{2, b)}$ \\ ${ }^{1,2}$ Jurusan Komunikasi dan Penyiaran Islam, IAIN Syekh Nurjati Cirebon \\ a) raniikawijayanti@gmail.com \\ b)syaefudinmochamad@gmail.com
}

\begin{abstract}
ABSTRAK
Pandemi Covid-19 yang melanda seluruh dunia masih menjadi sebuah masalah yang belum terselesaikan hingga saat ini dan menimbulkan banyak pro kontra di masyarakat. Joshua Irwandi, sebagai seorang jurnalis foto mencoba menghadirkan Covid-19 ke masyarakat dalam sebuah karya jurnalistik berupa foto yang ia unggah pada akun Instagramnya @joshirwandi. Dalam waktu singkat foto tersebut menjadi viral dan menjadi perbincangan di masyarakat. Foto sesosok tubuh manusia terbungkus plastic menjadi objek utama dalam penelitian ini. Penelitian ini menganalisis dampak dari virus Covid-19 yang memakan banyak korban yang direpresentasikan oleh Joshua Irwandi melalui foto jurnalistik dan dianalisis menggunakan analisis semiotika Roland Barthes. Dalam kajian semiotika, Roland Barthes memaparkan 3 tahapan untuk memaknai sebuah foto yaitu denotasi, konotasi, dan mitos. Hasil penelitian menunjukan bahwa virus corona yang tak kasat mata ini bukan hanya mitos belaka namun fakta karena telah menimbulkan banyak korban salah satunya buktinya adalah adanya foto sesosok jenazah yang terbungkus plastik karya Joshua irwandi. Foto ini mengajak masyarakat untuk sadar akan penyakit ini
\end{abstract}

Orasi: Jurnal Dakwah dan Komunikasi | Volume 11, No. 2, Desember 2020 
memang nyata dan berbahaya sehingga masyarakat diharapkan dapat menjaga kesehatan agar pandemi ini segera berlalu.

Kata Kunci: Analisis Semiotika, Foto Jurnalistik, Korban Covid-19, Representasi, Roland Barthes

\section{ABSTRACT}

The Covid-19 pandemic that has hit the entire world is still a problem not yet resolved to date and has created many pros and cons in society. Joshua Irwandi, as a photojournalist tried to bring Covid-19 to the public in a journalistic work in the form of a photo that he uploaded on his Instagram account @joshirwandi. In a short time, the photo went viral and became a hot topic in the community. A photo of a human body wrapped in plastic is the main object in this study. This study analyzed the impact of the pandemic, which took many victims, which was represented through photojournalism by Joshua Irwandi. The viral photo was analyzed using Roland Barthes' semiotic analysis. In a semiotic study, Roland Barthes describes 3 stages to interpret a photo, namely denotation, connotation, and myth. The research results show that the invisible corona virus was not just a myth but a fact because it had caused many victims; a photo of a body wrapped in plastic by Joshua Irwandi was the proof. This photo invited the public to be aware that this disease was real and dangerous so that people were expected to maintain their health to make this pandemic over soon.

Keywords: Covid-19 Victims, Photojournalism, Representation, Roland Barthes, Semiotic Analysis

\section{Pendahuluan}

Pada tanggal 15 Juli 2020 foto jenazah yang diduga korban Covid-19 di rumah sakit indonesia yang tubuhnya terbungkus lapisan plastik guna mencegah penyebaran virus menjadi viral di media sosial instagram. Foto karya Joshua Irwandi yang diambil untuk menyertai artikel pada majalah National Geographic edisi Agustus 2020 ini telah diposting dan disukai oleh lebih dari 300.000 orang pada akun Instagram pribadinya @joshirwandi. Pada tanggal 15 Juli 2020, foto serupa juga diunggah pada akun instagram @ natgeo dan lebih dari 1000.000 telah menyukai foto tersebut.

Tak hanya disukai, Foto jurnalistik ini juga menuai banyak perhatian salah satunya dari dari musisi tanah air Erdian Aji Prihartanto atau yang dikenal dengan sapaan Anji. "After Irwandi posted the photograph, a popular singer with a massive following accused the photographer of fabricating the news, said COVID-19 wasn't so dangerous, and opined that a photojournalist shouldn't be allowed to take a photograph in a hospital if the family could not see the victim. The singer's followers erroneously charged

Orasi: Jurnal Dakwah dan Komunikasi | Volume 11, No. 2, Desember 2020 
Irwandi with setting up the photo with a mannequin, and called him "a slave" of the World Health Organization. The 28-year-old photographer has received threats, and said he believes that the government has been trying to hunt down the hospital, unidentified in the image, where the body was photographed" (Beard 2020). Setelah seorang penyanyi popular dengan banyak pengikut menuduh fotografer membuat berita tersebut, mengatakan COVID-19 tidak begitu berbahaya, dan berpendapat bahwa seorang jurnalis foto tidak boleh mengambil foto di rumah sakit jika keluarga tidak bisa melihat korban. Pengikut penyanyi itu secara keliru menuduh Irwandi membuat foto dengan manekin, dan memanggilnya "budak" dari Organisasi Kesehatan Dunia.

Foto karya Joshua Irwandi menjadi semakin ramai diperbincangkan publik setelah Organisasi profesi Pewarta Foto Indonesia (PFI) mengecam keras dan serius pernyataan Anji melalui postingan di akun instagramnya @pewartafotoindonesia. PFI mengecam pernyataan Anji yang membuat opini penghakiman sepihak seolah-olah foto tersebut adalah hasil setting dan hasil karya dari seorang buzzer, bukan jurnalis. Menurut PFI dalam foto karya Joshua Irwandi itu digambarkan sesosok mayat terbungkus plastik yang meninggal akibat Covid- 19 di salah satu rumah sakit di Jakarta. PFI Pusat telah menghubungi Joshua Irwandi terkait foto tersebut untuk memastikan keabsahan dari karya jurnalistiknya yang viral itu. Dari hasil diskusi tersebut, Joshua telah mematuhi kode etik jurnalistik, mematuhi prosedur perijinan, dan mengikuti segala macam protokol kesehatan yang diwajibkan oleh pihak rumah sakit. Terkait hal tersebut di atas, PFI Pusat mengingatkan bahwa Kerja Jurnalistik dilindungi oleh Undang-Undang Nomor 40 Tahun 1999 tentang Pers dan Kode Etik Jurnalistik, untuk itu Pewarta Foto Indonesia (PFI) Pusat menyatakan sikap 1. Mengecam serta mengutuk opini yang tidak berimbang dan terkesan dibuat-buat dari Sdr. Anji yang menyebabkan keresahan dikalangan pewarta foto, fotografer, dan masyarakat umum. 2. Mendesak Sdr. Anji untuk menghapus postingan di Instagram terkait foto Joshua Irwandi. 3. Mendesak Sdr. Anji untuk meminta maaf secara terbuka akibat ulah yang telah ia perbuat kepada seluruh pewarta foto di Indonesia dan kepada Sdr. Joshua Irwandi. Karena PFI menilai hal ini merupakan bentuk pelecehan terhadap karya jurnalistik yang otentik dan pendiskreditan profesi. 4. Mendesak Sdr. Anji untuk meluruskan apa yang sebenarbenarnya terjadi sebelum, saat, dan sesudah prosesi pengambilan fotojurnalistik karya Joshua Irwandi di Instagram. 5. Tidak membandingkan kerja jurnalistik pewarta foto dengan anak agency, buzzer, influencer, youtuber, vlogger, dan sejenisnya. Karena kerja jurnalistik dilandasi oleh fakta yang ada di lapangan, memiliki kode etik yang jelas, 
dan dilindungi oleh undang-undang (Pewarta Foto Indonesia 2020).

Pernyataan resmi dari PFI kemudian di klarifikasi lebih lanjut oleh Anji, dengan menghapus postingan sebelumnya dan membuat respond balik kepada PFI. Dalam unggahan diakun instagram pribadinya @duniamanji, Anji mengatakan jika ia telah melakukan komunikasi dengan menghubungi via telepon pihak PFI melalui Hendra Sekjen PFI. Menurutnya ia tidak bermaksud mendiskreditkan profesi pewarta foto atau jurnalis. Secara karya foto, baginya foto karya Joshua Irwandi adalah sebuah foto yang powerful. Caption di Instagram adalah opininya dari sudut penyebaran informasi yang terasa janggal yang menurutnya sangat bisa didebat karena bisa salah dan bisa benar. Jadi yang dibahas dalam poin pertama postingannya adalah pola penyebaran informasinya bukan karya foto maupun pewartanya. Bukan juga tujuan Joshua mengambil foto tersebut. Kemudian pada poin kedua dia menjelaskan bahwa pertanyaannya menyangkut pada kode etik dunia kesehatan bukan kode etik jurnalisme karena menurut pemberitaan, korban covid19 tidak boleh ditemui oleh keluarganya. Menurutnya pertanyaan ini adalah pertanyaan orang awam. Dalam slide unggahan berikutnya, Anji menyatakan jika ia mengerti pasti ada etika untuk pewarta foto maupun jurnalis, dalam hal ini PFI pasti lebih tahu. Ia menegaskan bahwa pertanyaannya mengacu pada kode etik dunia kesehatan. Dalam slide selanjutnya Anji juga menuliskan permintaan maaf terbuka kepada PFI dan Joshua Irwandi serta 300 fotografer lainnya untuk penerimaan informasi yang berbeda. Dalam postingan di slide terakhir Anji menyatakan bahwa dirinya masih belum menemukan jawaban yang memuaskan dari sisi kode etik medis terhadap pasien covid-19 dan keluarganya. Ia juga mempersilahkan kepada para netizen untuk mendiskusikan jika ada jawaban yang bagus dan mengucapkan terima kasih kepada semua pihak yang telah perhatian (Manji 2020).

Diluar perdebatan tersebut, foto jurnalistik ini sebenarnya dibuat dengan tujuan untuk meningkatkan kesadaran masyarakat akan bahaya virus corona, untuk menghargai pekerjaan staf medis di Indonesia dan di seluruh dunia yang mempertaruhkan hidup mereka untuk menyelamatkan hidup kita, dan untuk mengingat bahwa kita harus tetap tabah dan bersatu dalam menghadapi pandemik ini (National Geographic 2020).

Dari pemaparan diatas maka rumusan masalah dalam peneltian ini adalah bagaimana representasi korban covid-19 dalam foto jurnalistik karya Joshua irwandi dalam akun media sosial instagram @joshirwandi. Peneliti tertarik unuk mengetahui makna apa yang dihadirkan lewat sajian foto jurnalistik terkait korban covid-19 karya pewarta foto Joshua Irwandi. Untuk itu 
peneliti melakukan riset guna memahami representasi korban covid 19 terhadap karya jurnalistik tersebut.

Menurut KBBI representasi adalah perbuatan mewakili, keadaan diwakili, apa yang diwakili, perwakilan (kbbi.kemdikbud.go.id 2020). Sedangkan Kata Fotografi berasal dari kata Photo yang berarti cahaya dan Graph yang berarti gambar. Dalam Kamus Ilmiah Populer disebutkan bahwa photo adalah gambar atau potret dari hasil kerja kamera. Sedangkan fotografi adalah pengetahuan teknik/seni pengambilan gambar dengan potret atau kamera. Orang yang melakukan foto disebut juga fotografer. Jurnalistik atau journalisme berasal dari perkataan journal, artinya catatan harian, atau catatan mengenai kejadian sehari-hari, atau bisa juga berarti suratkabar. Journal berasal dari perkataan Latin diurnalis, harian atau tiap hari. Dari perkataan itulah lahir kata jurnalis, yaitu orang yang melakukan pekerjaan jurnalistik. Jadi, fotografi jurnalistik yaitu kegiatan fotografi yang bertujuan merekan jurnal peristiwa-peristiwa yang menyangkut manusia (Nuswantara 2014).

Media sosial bisa diartikan sebagai alat komunikasi sebagaimana yang diketahui. Media juga bisa dipahami dengan melihat dari proses komunikasi itu sendiri yang memerlukan tiga hal yaitu objek, organ, dan medium (Nasrullah 2015).
Instagram merupakan aplikasi dimana pengguna dapat berbagi foto yang memungkinkan pengguna mengambil foto, menerapkan filter digital, dan membagikannya ke berbagai layanan jejaring social, termasuk pemilik Instagram sendiri. Instagram juga memungkinkan followers saling berkomentar dengan pemilik akun di foto yang diunggahnya (Pratiwi dan Nasution 2017).

Semiotik adalah ilmu tentang tandatanda. Studi tentang tanda dan segala yang berhubungan dengannya, cara berfungsinya, hubungannya dengan tanda -tanda lain, pengirimannya dan penerimaannya oleh mereka yang menggunakannya. Menurut Preminger (2001), Ilmu ini menganggap bahwa fenomena sosial atau masyarakat dan kebudayaan itu merupakan tanda-tanda. Semiotik mempelajari sistem-sistem, aturanaturan, konvensi-konvensi yang memungkinkan tanda-tanda tersebut mempunyai arti. Analisis semiotik berupaya menemukan makna tanda termasuk hal-hal yang tersembunyi di balik sebuah tanda (teks, iklan, berita). Karena sistem tanda sifatnya amat kontekstual dan bergantung pada pengguna tanda tersebut. Pemikiran pengguna tanda merupakan hasil pengaruh dari berbagai konstruksi sosial dimana pengguna tanda tersebut berada (Kriyantono 2014).

Semiotik juga merupakan alat untuk menganalisis gambar-gambar (images) yang 
luar biasa. Meskipun terminologi-terminologi (signifier, signified, paradigm, syntagm, synchronic, diachronic, dan sebagainya) mungkin awalnya terlihat membingungkan, semiotic adalah disiplin yang penting dalam studi tentang bahasa media (Ida 2014).

Salah satu wilayah penting yang dirambah Barthes dalam studinya tentang tanda adalah peran pembaca (The Reader). Barthes beranggapan bahwa peran seorang pembaca (reader) sangat penting, karena akan menunjukkan apakah pesan yang disampaikan melalui sebuah tanda tersebut dapat diterima atau tidak. Barthes memaparkan pengertian denotasi sebagai signifikas tingkat pertama melihat bahwa denotasi memiliki makna yang sebenarnya (Aprilianingrum 2019).

Penelitian ini diharapkan dapat meningkatkan kesadaran masyarakat terhadap bahaya virus corona melalui foto jurnalistik karya joshua irwandi tentang jenazah korban covid-19 yang terbungkus rapi menggunakan plastik, terutama masyarakat yang tidak percaya dan menganggap sebagai teori konspirasi semata.

\section{Metodologi Penelitian}

Penelitian ini menggunakan pendekatan kualitatif dengan analisis semiotika Roland Barthes. Objek dalam penelitian ini adalah foto terkait korban covid-19 di Instagram @joshirwandi.

Teknik pengumpulan data dalam penelitian ini menggunakan kepustakaan dan dokumentasi. Adapun teknik analisis data yang digunakan adalah teknik analisis Roland Barthes.

Roland Barthes adalah salah satu tokoh semiotika yang menggali maknamakna dalam sebuah tanda. Teknik analisis data Roland Barthes terdiri dari signifikasi dua tahap (two order of significations) yaitu denotasi, konotasi dan mitologi. Makna denotasi dalam sebuah foto adalah makna yang tampak secara kasat mata. Sedangkan makna konotatif berada dalam tingkatan di atas makna denotasi, yaitu makna yang dapat diterjemahkan melalui makna kultural yang bertaut dalam sebuah terminologi tertentu di masyarakat (Wijaya 2014).

Roland Barthes menyebutkan dalam bukunya yang berjudul "Image, Music, Text" memaparkan bahwa ada 3 tahapan untuk memaknai sebuah karya foto untuk menentukan wacana dan paradigma apa yang berkaitan dengan ideologi tertentu (Putra 2017).

a. Tahap Perseptif merupakan tahap awal untuk mentransformasi foto / gambar ke dalam kategori verbal foto / gambar yang masih memiliki sifat imajinatif.

b. Tahap Konotasi Kognitif yakni tahapan kedua untuk mengumpulkan serta berupaya menghubungkan unsur-unsur "historis" dari denotasi ke dalam imajinasi paradigmatik. Dalam tahap ini pengetahuan kultural sangatlah 
menentukan dalam membaca sebuah foto / gambar.

c. Tahap Etis-Ideologis adalah tahap pengumpulan berbagai penanda yang siap "dikalimatkan" sehingga motifnya dapat ditentukan.

\section{Hasil dan Pembahasan}

Objek penelitian ini adalah foto karya Joshua Irwandi yang diunggah ke akun Instagramnya @joshirwandi pada 15 Juli 2020.
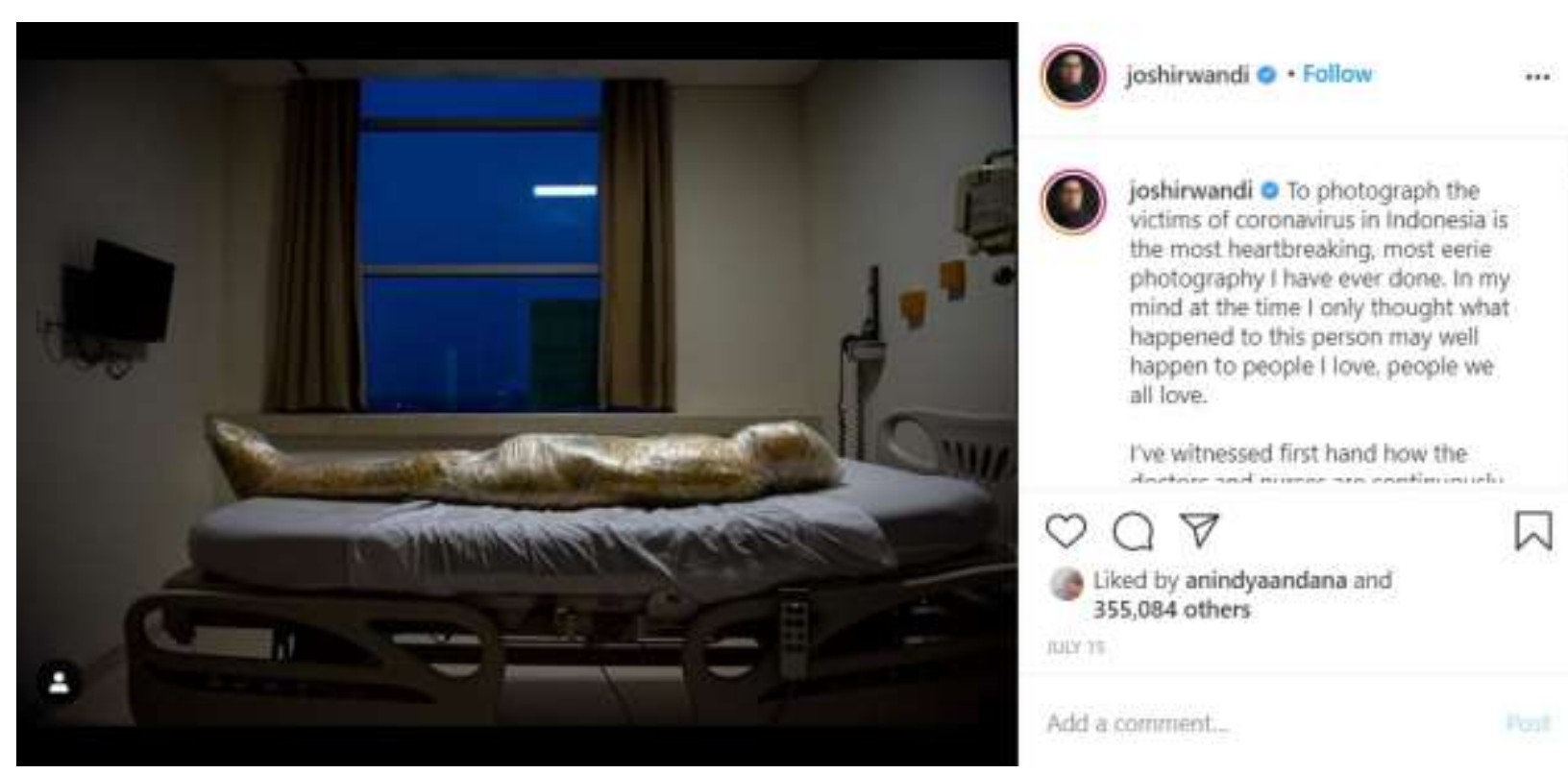

Gambar 1. Foto Korban Covid 19 Dalam Akun Instagram @joshirwandi Sumber: https://www.instagram.com/p/CCp0qI0A4lG/

\subsection{Denotasi}

Pada foto tersebut nampak sesosok tubuh manusia yang merupakan jenazah akibat Covid-19 terletak di atas sebuah tempat tidur. Sosok ini nampak kaku terbungkus oleh lapisan-lapisan plastik di sekujur tubuhnya. Jenazah terbungkus plastik ini menunjukkan treatment yang diberikan oleh para tenaga kesehatan dalam pemulasaraan jenazah dengan cara yang berbeda dengan biasanya. Jenazah yang positif Covid dibungkus dengan kain kafan lalu dibalut lagi dengan plastic yang berlapis- lapis untuk menghindari penyebaran virus Covid 19 ke manusia yang masih sehat. Setting lokasi menunjukkan bahwa foto ini diambil di sebuah rumah sakit, hal ini terpampang melalui perabotan-perabotan yang ada di situ. Terdapat bed, alat pengukur tekanan darah, televisi dan sebagainya. Cahaya lampu yang temaram menambah aura suram ketika memandang foto tersebut. Kumpulan tanda dan petanda dalam tataran denotatif ini menunjukkan secara kasat mata apa saja yang terekam dalam frame. Selain itu, foto ini juga memiliki caption yang 
ditulis untuk membantu menjelaskan maksud dari foto tersebut.

"To photograph the victims of coronavirus in Indonesia is the most heartbreaking, most eerie photography I have ever done. In my mind at the time I only thought what happened to this person may well happen to people I love, people we all love.

I've witnessed first hand how the doctors and nurses are continuously risking their lives to save ours. They are the true heroes of this story, and the only way to appreciate their work is to follow what they advise us. We felt it was absolutely crucial that this image must be made. To understand and connect to the human impact of this devastating virus. The image is published here today as a reminder and a warning, of the ever looming danger. To inform us of the human cost of coronavirus and how world governments have let matters get so far. As we head towards the second wave of the pandemic, people must realise they cannot take this matter lightly.

This photograph accompanies an article that appears in the National Geographic Magazine@ @atgeo in the new upcoming August 2020 issue. LINK IN BIO. It is also the first time I'd see the image in print. There are many people to thank, most notably@kayaleeberne, in which this is the first print $N G$ story she edited; @jamesbwellfordfor reacting on the story from early on; @andritambunan, @kkobre, and@paullowephotographyfor their advice; and last but not least my mentor@geertvankesterenphotofor his unrelenting support since day one. I would like to dedicate this to the medical staff - whose selfless efforts allow us to continue to live. I am truly humbled to be in their midst countering this pandemic. And to my late Uncle Felix who, two years before he passed away earlier this year, sent me an email: 'Keep on taking pictures and never fail to report to let the world know what has really happened.'

Please share this story and please act. This is the pandemic of our lifetime. We must win this battle.

Supported by the@forhannafoundation and @insi denatgeo COVID-19 Emergency Fund for Journalist. @ natgeointhefield \#natgeo \#joshuair wandi \#natgeoemergencyfund \#docu mentaryphotography \#photography \#covid19 \#covidstories \#nationalgeo graphicsociety \#pandemic \#stayatho me."

\subsection{Konotasi}

Dalam foto ini, sosok jenazah yang terbungkus plastik ini adalah tanda dalam semiology Barthes. Tanda yang tampak secara denotatif ini dapat disebut juga menjadi penanda konotatif dalam level selanjutnya.

a. Ciri fisik

Dalam foto ini, sosok jenazah Nampak dibalut dengan kain kafan dan plastik. Kain kafan adalah sebuah kain yang berwarna putih dan digunakan untuk membungkus jenazah khususnya dalam agama Islam. Namun, penggunaan kain kafan pada jenazah juga dikenal di agama Kristen karena para ilmuwan telah menemukan kain kafan yang membalut tubuh Yesus Kristus saat dikubur (Fanti 2018). Plastik disini juga menjadi simbolisasi kekekalan karena sifatnya yang tidak mudah diuraikan. Secara 
makna konotasi, pelapisan atau pembungkusan tubuh manusia yang telah meninggal ini menggambarkan bahwa ia sudah terikat di alam arwah dan tidak bisa lagi kembali ke dunia. Segala amal ibadah, dosa dan seluruh perbuatannya harus dipertanggungjawabkan dan tidak ada lagi kesempatan untuk memperbaikinya.

b. Komposisi dan Teknik Pengambilan Gambar

Teknik pengambilan gambar yang digunakan dalam foto ini menggunakan long shot karena jarak antara fotografer dan objek yang cukup jauh sehingga objek nampak lebih kecil (Alwi 2016). Penggunaan long shot dan peletakan kamera secara horizontal mampu menangkap keseluruhan unsur dalam ruangan tersebut sehingga suasana atau mood dalam foto tersebut dapat diproyeksikan secara utuh. Angle yang digunakan pada foto ini adalah eye-level angle yang menemparkan objek di tengah frame sejajar dengan mata pembaca.

c. Warna

Warna kain kafan yang membungkus jenazah tersebut memilliki asosiasi dengan suci, bersih, sempurna (Basuki 2015). Kematian menjadi tahap akhir dalam perjalanan kehidupan manusia yang dianggap menjadi titik terakhir kesempurnaan dalam kehidupan. Orang yang meninggal tidak serta merta dikuburkan tetapi disucikan agar kembali kepada Tuhan dalam kondisi yang bersih. Warna putih juga dapat dilambangkan menjadi warna perlambang kematian dalam budaya Jepang dan Cina. (Monica and Luzar 2011). Selain warna putih, di dalam foto ini juga terdapat unsur warna biru. Biru seringkali diasosiasikan dengan kondisi yang tenang, damai, sejuk. Apabila dikaitkan dengan foto ini maka orang yang meninggal tersebut diharapkan kembali kepada Tuhan dengan kondisi damai dan tenang walaupun dalam kesendirian karena tidak didampingi oleh keluarganya demi menekan penyebaran virus Covid 19.

\section{d. Pencahayaan}

Pencahayaan dalam foto ini terlihat redup dan suram. Hal ini memiliki makna kesedihan, muram, kehilangan. kesendirian, kehampaan, kosong. Sejak awal mereka yang terkonfirmasi mengidap penyakit ini di isolasi di dalam sebuah kamar di rumah sakit dengan minimal interaksi dengan sesama manusia. Apabila mereka tidak mampu bertahan ketika dalam proses pengobatan, mereka akan meninggal dalam kondisi kesendirian. Tidak boleh ada kerabat yang melakukan ritual-ritual penghormatan kepada jenazah seperti biasanya.

e. Teks

Caption adalah bagian yang tak terpisahkan dari sebuah foto. Di dalam caption tersebut, sang fotografer menuliskan pengalaman betapa ngerinya saat harus bertugas mengambil foto tersebut. Tanggung jawab sebagai seorang jurnalis professional pun ia emban guna menginformasikan betapa 
nyata dan bahayanya virus ini melalui foto seorang korban agar masyarakat lebih sadar dalam menjaga kesehatan dan kebersihan. Ia membayangkan betapa banyaknya tenaga, uang, waktu yang dipertaruhkan oleh para tenaga kesehatan untuk menyembuhkan orang yang terkena virus Covid 19. Ia juga membayangkan kondisi pasien yang harus berjuang melawan penyakit sendirian tanpa ditemani keluarga. Apalagi jika pasien tersebut tidak tertolong maka pasien juga harus meninggal dalam kesendirian.

\subsection{Mitos}

Pandemi Covid 19 ini bukanlah masalah yang dialami oleh satu wilayah atau satu negara saja. Seluruh dunia merasakan dampak yang besar akibat virus ini. Sektor kesehatan menjadi salah satu sektor yang sedang dihajar habis-habisan, seperti banyaknya pasien, angka kematian meningkat tajam. tenaga kesehatan yang berjuang mati-matian untuk merawat pasien, obat dan vaksin yang belum teruji dapat menyembuhkan total pasien yang sakit dan melindungi yang sehat serta lain sebagainya. Hal ini menyebabkan dampak negatif ke sektor lainnya seperti pendidikan, pariwisata, ekonomi yang ditunjukkan dengan berbagai masalah. Masalah-masalah seperti terhambatnya proses pendidikan, PHK, lesunya pariwisata dan bisnis, kejahatan, kekerasan dan masalah lain yang diakibatkan oleh pandemi yang berkepanjangan.
Maka sudah sewajarnya kita sebagai warga gegara untuk menumbuhkan kembali ideologi nasionalisme. Rasa cinta pada negara yang ditunjukkan dengan sikap rela berkorban untuk mewujudkan kedaulatan. Ideologi nasionalisme ini tidak akan berjalan sendirian tanpa sinergitas dari masyarakat dan pemerintah. Tidak hanya menumbuhkan kembali, namun juga meredefinisi nasionalisme menjadi sebuah rasa saling berjuang dan mengutamakan kepentingan bangsa untuk melawan pandemi.

\section{Simpulan}

Menurut Barthes, sebuah foto yang begitu fenomenal atau viral di masyarakat biasanya memiliki pesan yang kuat didalamnya. Dalam kajian semiotika, emosi, persepsi dan pengalaman masing-masing individu dalam kehidupannya memainkan sebuah peranan yang penting untuk memaknai sebuah foto. Maka dari itu satu foto yang sama dapat menimbulkan berbagai pemaknaan yang berbeda jika dimaknai oleh orang yang berbeda pula (Wijaya 2014).

Selama masa pandemi yang terjadi dalam kurun waktu 8 bulan ini banyak sekali pro kontra tentang eksistensi Covid-19 di Indonesia. Data tentang peningkatan jumlah warga yang terkena virus Covid-19 dan data tentang kematian akibat pandemi ini selalu hadir menghiasi saluran-saluran berita. Sudah banyak orang yang meninggal akibat virus ini baik dari kalangan awam maupun tenaga 
kesehatan, namun masih banyak juga warga yang tidak percaya atau menyangkal akan hadirnya virus ini. Joshua berusaha menampilkan virus Covid-19 yang tidak kasat mata ini kedalam wujud nyata melalui sebuah karya foto jurnalistik.

Mitos tentang keberadaan virus ini menjadi nyata dengan adanya sesosok jenazah yang terbungkus plastik dan kemudian menjadi viral di sosial media. Foto ini mengajak masyarakat untuk sadar akan penyakit ini memang nyata dan berbahaya sehingga masyarakat diharapkan dapat menjaga kesehatan agar pandemi ini segera berlalu. Selain itu perlunya menumbuhkan rasa nasionalisme demi kepentingan dan kedaulatan negara agar bisa kembali bangkit dan beraktivitas seperti sedia kala tanpa harus khawatir akan terinfeksi virus.

\section{Daftar Pustaka}

Alwi, Audy Mirza. 2016. FOTO JURNALISTIK Metode Memotret Dan Mengirim Foto Ke Media Massa. Jakarta: PT. Bumi Aksara.

Aprilianingrum, Dian. 2019. "Representasi Bencana Dalam Foto Seri Cerita Kloset Pascagempa-Tsunami Palu (Studi Analisis Semiotik Terhadap Foto Seri Karya Beawiharta Yang Dimuat Di Beritasatu.Com)" Jurnalisa Vol 05 Nomor 1: $\quad 31-42$ DOI: http://dx.doi.org/10.24252/jurnalisa.v5i 1.9896 diakses 24 Juli 2020

Basuki, Achmad. 2015. "Makna Warna Dalam Desain." Retrieved April 30: 2017.

Beard, David. 2020. "Photo of COVID-19
Victim in Indonesia Sparks Fascination-and Denial.” 2020. https://www.nationalgeographic.com/ph otography/2020/07/covid-victim-

photograph-sparks-fascination-anddenial-indonesia/.

Fanti, Giulio. 2018. "Why Is the Turin Shroud Not Fake?" Global Journal of Archaeology \& Anthropology 7 (3). https://doi.org/10.19080/gjaa.2018.07.5 55715.

Ida, Rachmah. 2014. "Studi Media dan Kajian Budaya”. Jakarta: Prenada.

Kriyantono, Rachmat. 2014.'”Teknik Praktis Riset Komunikasi. ”Jakarta: Kencana Prenada Media.

Monica, Monica, dan Laura Christina Luzar. 2011. "Efek Warna Dalam Dunia Desain Dan Periklanan." Humaniora 2 (2): 1084. https://doi.org/10.21512/humaniora.v2i 2.3158 .

Nasrullah, Rulli. 2015. Media Sosial Perspektif Komunikasi, Budaya Dan Sosioteknologi. Bandung: Simbiosa Rekatama.

Nuswantara, Jaka Priyo. 2014. "Pesan Sosial Dalam Foto Jurnalistik (Analisis Semiotika Dalam Buku 'Jakarta Estetika Banal', Bab I, III, V, dan VII)" Jurnal The Messenger Vol 6 No 1:14-21 DOI:

http://dx.doi.org/10.26623/themessenge r.v6i1.163 diakses 24 Juli 2020

Pratiwi, Endah Rizqi dan Belli Nasution 2017. "Foto Bencana Asap Di Provinsi Riau Pada Instagram @Infopku_ (Analisis Semiotika Roland Barthes)" JOM FISIP Volume 4 No. 2: 1-14 DOI: https://jom.unri.ac.id/index.php/JOMFS IP/article/view/15166/14713 diakses 28 Juli

Putra, Sandi Justitia. 2017. "Representasi Wanita Indonesia Pada Foto Jurnalistik 
(AnaPutra, Sandi Justitia. 2017. 'Representasi Wanita Indonesia Pada Foto Jurnalistik (Analisis Semiotika Roland Barthes Pada Foto Jurnalistik "Pengukuhan Paskibraka" Dalam Media Online Tempo.Co).' In Se.” In Seminar Nasional TIK Dan Ilmu Sosial (SocioTech).

Sobur, Alex. 2007. "Analisis Teks Media." Bandung: Rosda.

Wijaya, Taufan. 2014. Foto Jurnalistik. Jakarta: PT. Gramedia Pustaka Utama. 